\title{
Contents, Vol. 3, 1980
}

\section{Biochemistry}

Sternberg, M. and Spiro, R. G.: Studies on the Catabolism of the Hydroxylysine-Linked

Disaccharide Units

of Basement Membranes and Collagens. Isolation and Characterization of a New Rat-Kidney $\alpha-$ Gluco-

sidase of High Specificity 1

Lubec, G. and Pollak, A.: Reduced Susceptibility of Nonenzymatically Glucosylated Glomerular

Basement

Membrane to Proteases. Is Thickening of Diabetic Glomerular Basement Membranes Due to

Reduced

Proteolytic Degradation? 4

Hudson, B.G. and Wesley Fox, J.: Characterization of the Collagenous Domain of Bovine

Glomerular

Basement Membrane 9

Butkowski, R. J.; Grantham, J. J., and Hudson, B.G.: Comparison of the Chemical and

Polypeptide Com

position of Tubular and Glomerular Basement Membranes 14

Trüeb, B.; Odermatt, B. F.; Sahu, A. P.; Spiess, M.; Rüttner, J. R., and Winterhalter, K. H.: Type IV Collagen

Is a Heteropolymer with the Formula C2D 23

Benya, P. D.: EC Collagen: Biosynthesis by Corneal Endothelial Cells and Separation from Type IV without

Pepsin Treatment or Denaturation 30

Heathcote, J.G.; Muhammed, S.; Smith, E. F., and Grant, M.E.: Biosynthetic Studies on the

Collagenous

Components of Basement Membranes

Price, R.G.; Taylor, S. A., and Khalil-Manesh, F.: Differential Solubility and Subunit

Composition of Rat

Glomerular Basement Membrane 41

Price, R. G.; Kang, S. S.; Taylor, S. A.; Khalil-Manesh, F., and Yudkin, J.: Composition and

Biosynthesis of

Glomerular Basement Membrane in Rats Fed Diets Rich in Sucrose

Langeveld, J.P. M. and Veerkamp, J. H.: Chemical Characterization of Glomerular and Tubular

Basement

Membranes of Various Mammalian Species 56

Langeveld, J.P. M.; Veerkamp, J. H., and Monnens, L. A. H.: Variations in Chemical

Composition of Human

Glomerular and Tubular Basement Membranes with Age and Disease

Meezan, E. and Freychet, P.: Specific Insulin Receptors in Rat Renal Glomeruli 
Cortes, P.; Dumler, F.; Levin, N.W.; Venkatachalam, K. K; Spargo, B.H, and Goldman, J.: Glomerular

Pyrimidine Metabolism in Experimental Diabetic Nephropathy

Minuth, W.W. and Kriz, W.: Newly Synthesized Proteins in Rat Glomerular Fractions $\quad 88$

Matsuo, E. and Yamada, K.: Acid Mucopolysaccharide and One of Its Degrading Enzymes B-

Glucuronidase

in Experimental and Human Glomerulonephritis $\quad 97$

Davies, M.; Coles, G.A., and Hughes, K.T.: Glomerular Basement Membrane Injury by

Neutrophil and

Monocyte Neutral Proteinases

106

Davies, M.; Hughes, K.T., and Thomas, G.J.: The Binding of Human Lysosomal Elastase to

Glomerular

Basement Membrane 112

Davies, M.; Hughes, K.T., and Thomas, G.J.: Evidence that Kidney Lysosomal Proteinases

Degrade the

Collagen of Glomerular Basement Membrane

116

Velosa, J.A.; Shah, S.V.; Ou, S.-L.; Abboud, H. E., and Dousa, T.P.: Glomerular Lysosomal

Enzymes in

Aminonucleoside Nephrosis 120

Lubec, G.; Förster, O.; Coradello, H.; Maxa, E., and Pollak, A.: Proteolytic Degradation of the Glomerular

Basement Membrane and Immunochemical Characterization of Split Products 126

Bray, B. A.; Turino, G. M., and Mandl, I.: Human Basement Membrane Antigens from Lung, Placenta and

Kidney 133

Brendel, K; Duhamel, R.C.; Spall, R.D., and Meezan, E.: Rabbit Glomerular and Tubular

Basement

Membranes: Morphology and Differential Solubilization 145

VI

Contents

Sperk, G.; Ratzenhofer, E.; Simbruner, G.; Coradello, H.; Pollak, A., and Lubec, G.: Evidence for $\mathrm{H} 2 \mathrm{Re}$

ceptor Activity on Glomerular Cells 152

Hunt, J.S.; Macdonald, P.R., and McGiven, A.R.: Isolation of Human Glomerular Basement

Membrane

Antigens by Affinity Chromatography Utilising Goodpasture's Kidney Antibody Eluates 156

Chanard, J.; Szymanowicz, A.; Brunois, J.-P.; Toupance, O.; Birembaut, P., and Borel, P.J.:

Urinary

3-Hydroxyproline in Renal Disease 163

Foidart, J.B.; Pirard, Y.S.; Winand, R.J., and Mahieu, P.R.: Tissue Culture of Normal Rat

Glomeruli.

Glycosaminoglycan Biosynthesis by Homogeneous Epithelial and Mesangial Cell Populations 169

Foidart, J.B.; Goffinet, G.; Dubois, C; Dechenne, C, and Mahieu, P.R.: Isolation and

Characterization of

Rat Renal Glomerular Cells in vitro 174 
Foidart, J.M.; Foidart, J.B., and Mahieu, P. R.: Synthesis of Collagen and Fibronectin by Glomerular Cells in

Culture $\quad 183$

Biology

Brownell, A.G. and Slavkin, H.C.: Role of Basal Lamina in Tissue Interactions 193

Huang, T.W. and Benditt, E.P.: Human Platelets and Glomerular Basal Lamina Interaction 205

Nayyar, R.P.; Volini, F.I., and Borke, J. L.: The Role of Visceral Epithelial, Endothelial and Mesangial Cells

in the Formation and Turnover of Glomerular Basement Membrane $\quad 212$

Rytter Nørgaard, J. O.: Origin of Outgrowth from Isolated Glomeruli in Culture 220

Krakower, C.A. and Manaligod, J.R.: Mesangiolysis of Isolated Renal Glomeruli with the

Formation of

Lobular Sacs or Cysts 226

Schurer, W.; Fleuren, G.J.; Hoedemaeker, P.J., and Molenaar, I.: A Model for the Glomerular

Filter .. 237 Nagase, M. and Honda, N.: Protein Permeability and Immune Complex Deposition in Glomerular Capillary

Walls of Rats 244

Cavallo, T.: Glomerular Permeability. Alteration in Size- and Charge-Based Barrier Function in

Lupus

Nephritis 250

Evan, A.P. and Luft, F.C.: Effect of Alloxan-Induced Diabetes on the Glomerular Filtration

Barrier of the

Rat 257

Luft, F.C. and Evan, A.P.: Glomerular Filtration Barrier in Aminoglycoside-Induced

Nephrotoxic Acute

Renal Failure 265

Simpson, L. O.: Biological Thixotropy of Glomerular Basement Membrane and the Implications of Thi-

oxotropy in Explaining Basement Membrane Permeability 272

Morphology

Carlson, E.C. and Kenney, M.C.: Preparation and Histoarchitecture of Ultrastructurally Pure

Glomerular

Basement Membrane 280

Carlson, E.C. and Kenney, M.C: Mophological Heterogeneity of Isolated Renal Basement

Membranes 288

Østerby|, R.; Gundersen, H. J. G.; Gøtzsche, O.., and Seyer-Hansen, K.: The Rate of Synthesis and Breakdown

of Glomerular Basement Membrane Material at the Transition 'Normal to Diabetes' and

'Diabetes to

Normal' 298

Gundersen, H. J.G. and Østerby, R.: Precise Quantitation of Glomerular Basement Membrane

Mopho-

logy 303

Huang, T.W.: Structural Organization of Heterogeneous Basal Laminas in Human Glomeruli 312 
Ota, Z.; Makino, H.; Takaya, Y., and Ofuji, T.: Molecular Sieve in Renal Glomerular and Tubular Basement

Membranes as Revealed by Electron Microscopy $\quad 317$

Romen, W.; Heck, T.; Rauscher, G.; Lange, H.U., and Hempel, K: Glomerular Basement Membrane

Turnover in Young, Old, and Streptozotocin-Diabetic Rats 324

Oemar, B.S.; Buss, H., and Hollweg, G.: Influence of the Lectins and Polycation on the

Configuration of

Renal Podocytes. A Scanning Electron Microscopic Study of Renal Podocytes after

Micropuncture of the

Glomerulus in vivo 330

Contents VII

Pathology

Batsford, S.; Oite, T.; Takamiya, H., and Vogt, A.: Anionic Binding Sites in the Glomerular

Basement

Membrane: Possible Role in the Pathogenesis of Immune Complex Glomerulonephritis 336

Wieslander, J.; Gygren, P., and Heinegård, D.: Different Antibody Response in Experimental and Spon

taneous Glomerulonephritis 341

Pabico, R.C.; Panner, B.J.; McKenna, B.A., and Bryson, M.F.: Glomerular Lesions in Patients with

Late-Onset Cystinosis with Massive Proteinuria 347

Sanders, E.; Davies, M., and Coles, G.A.: On the Pathogenesis of Glomerulonephritis. A ClinicoPatho-

logical Study Indicating that Neutrophils Attack and Degrade Glomerular Basement Membrane .... 355

Wakashin, M.; Wakashin, Y.; Ueda, S.; Takei, I.; Mori, Y.; Mori, T.; Iesato, K., and Okuda, K.:

Murine

Autoimmune Interstitial Nephritis and Associated Antigen: Purification of a Soluble Tubular

Basement

Membrane Antigen from Mice Kidneys

360

Hunt, J. S.; McGiven, A.R.; Jackson, A.E., and Day, W. A.: Macrophages in NZB/NZW Mouse

Glomerular

Disease $\quad 368$

Oe, P.L.; Ooms, E.C. M.; Uttendorfsky, O. T.; Stolte, L. A.M.; Delden, L. van, and Graaff, P.:

Postpartum

Resolution of Glomerular Changes in Edema-Proteinuria-Hypertension Gestosis 375

Rakotoarivony, J.; Orfila, J. C.; Dubois, C.; Bardos, P.; Muh, J. P.; Mahieu, P., and Sue, J.M.:

Specificity

and Nephrotoxicity of Heterologous Antibodies Directed Against Renal Basement Membranes 380

Colasanti, G.; Moran, J.; Bellini, A., and D’Amico, G.: Significance of Glomerular C3b

Receptors in Human

Renal Diseases 
Gubler, M.C.; Levy, M.; Naizot, C, and Habib, R.: Glomerular Basement Membrane Changes in Non-

hereditary Glomerular Diseases 395

Gubler, M.C.; Levy, M.; Naizot, C, and Habib, R.: Glomerular Basement Membrane Changes in Heredi

tary Glomerular Diseases 405

Droz, D.; Noel, L. H.; Nabarra, B., and Leibowitch, J.: The Dense Deposits Disease of the Renal Basement

Membranes 414

Schneider, P.: Capsular Basement Membrane Alterations After Tubulus Atrophy and

Glomerulosclerosis in

the Dog Kidney. Contribution to the Pathology of Basement Membrane Genesis 418

Lange, C. F.: Glomerular Basement Membrane: Its Antigenicity Evaluated by Antistreptococcal Cell Mem

brane Antisera

424

Author Index 433

Due to organizatory reasons only, the rest of the proceedings will be published in one of the next issues of this journal. 